\title{
Genomic profiling of rectal adenoma and carcinoma by array-based comparative genomic hybridization
}

\author{
Zhi-Zhou Shi ${ }^{1}$, Yue-Ming Zhang ${ }^{2}$, Li Shang ${ }^{1}$, Jia-Jie Hao ${ }^{1}$, Tong-Tong Zhang ${ }^{1}$, Bo-Shi Wang ${ }^{1}$, Jian-Wei Liang ${ }^{3}$, \\ Xi Chen ${ }^{1}$, Ying Zhang ${ }^{1}$, Gui-Qi Wang ${ }^{2}$, Ming-Rong Wang ${ }^{1 *}$ and Yu Zhang ${ }^{1 *}$
}

\begin{abstract}
Background: Rectal cancer is one of the most common cancers in the world. Early detection and early therapy are important for the control of death caused by rectal cancer. The present study aims to investigate the genomic alterations in rectal adenoma and carcinoma.

Methods: We detected the genomic changes of 8 rectal adenomas and 8 carcinomas using array CGH. Then 14 genes were selected for analyzing the expression between rectal tumor and paracancerous normal tissues as well as from adenoma to carcinoma by real-time PCR. The expression of GPNMB and DIS3 were further investigated in rectal adenoma and carcinoma tissues by immunohistochemistry.

Results: We indentified ten gains and 22 losses in rectal adenoma, and found 25 gains and 14 losses in carcinoma. Gains of 7p21.3-p15.3, 7q22.3-q32.1, 13q13.1-q14.11, 13q21.1-q32.1, 13q32.2-q34, 20p11.21 and 20q11.23-q12 and losses of 17p13.1-p11.2, 18p11.32-p11.21 and 18q11.1-q11.2 were shared by both rectal adenoma and carcinoma. Gains of 1q, 6p21.33-p21.31 and losses of 10p14-p11.21, 14q12-q21.1, 14q22.1-q24.3, 14q31.3-q32.1, 14q32.2-q32.32, $15 q 15.1-q 21.1,15 q 22.31$ and 15q25.1-q25.2 were only detected in carcinoma but not in adenoma. Copy number and mRNA expression of EFNA1 increased from rectal adenoma to carcinoma. C13orf27 and PMEPA1 with increased copy number in both adenoma and carcinoma were over expressed in rectal cancer tissues. Protein and mRNA expression of GPNMB was significantly higher in cancer tissues than rectal adenoma tissues.
\end{abstract}

Conclusion: Our data may help to identify the driving genes involved in the adenoma-carcinoma progression.

\section{Background}

Rectal cancer is the 5th leading cause of cancer-related death and its incidence is increasing at a rate of $4.2 \%$ per year in China [1]. Early detection and early therapy are important for the control of death caused by rectal cancer.

The majority of epithelial cancers arise through a stepwise progression from normal cells, through dysplasia, into malignant cells that have invasive and metastatic potential. The classic example of this process is the colorectal adenoma to carcinoma progression [2,3]. Genomic aberrations are found frequently in cancers and are believed to contribute to initiation and progression of

\footnotetext{
*Correspondence: wangmr2015@cicams.ac.cn; zhangyu909@126.com ${ }^{1}$ State Key Laboratory of Molecular Oncology, Cancer Institute /Hospital, Peking Union Medical College and Chinese Academy of Medical Sciences, Beijing, China

Full list of author information is available at the end of the article
}

cancer by deletion-induced down-expression of tumor suppressor genes or amplification and activation of oncogenes. In colorectal cancer the most frequent chromosomal aberrations were gains at $7 \mathrm{p}, 7 \mathrm{q}, 8 \mathrm{q}, 13 \mathrm{q}$, and $20 \mathrm{q}$ and losses of $1 \mathrm{p}, 4 \mathrm{p}, 4 \mathrm{q}, 5 \mathrm{q}, 8 \mathrm{p}, 14 \mathrm{q}, 15 \mathrm{q}, 17 \mathrm{p}$ and $18 \mathrm{q}$ [4-9]. In particular, $8 \mathrm{q}, 13 \mathrm{q}$ and $20 \mathrm{q}$ gains and 8 p, 15q and 18q losses are linked with colorectal adenoma to carcinoma progression. However, most of published reports are focused on colon cancer. Little information is available concerning the genomic aberrations of rectal carcinoma, especially DNA copy number changes in the progression from adenoma to tumor.

In the present study, we investigated the genomic aberrations of rectal adenoma and carcinoma by oligonucleotide-based array CGH, and identified common and different alterated chromosome regions between rectal adenoma and carcinoma. Then the expression of 15

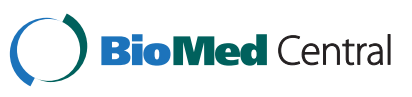


genes at selected chromosome regions above was analyzed by real-time PCR or immunohistochemistry.

\section{Methods}

\section{Patients and samples}

Biopsy tissues from 22 rectal adenoma patients and 36 rectal carcinoma patients were collected by the Department of Endoscopy, Cancer Hospital, Peking Union Medical College and Chinese Academy of Medical Sciences, Beijing, China. Biopsy samples were obtained by colonoscopy and stored at $-80^{\circ} \mathrm{C}$. Definitive pathological result from a biopsy was obtained at a later clinical course. An experienced pathologist confirmed that normal cell content of all the samples was less than $40 \%$ by HE staining. All the samples used in this study were residual specimens after diagnosis sampling. And all patients signed separate informed consent forms for sampling and research. The clinicopathological characteristics of the patients in array CGH assay are summarized in Table 1.

\section{Genomic DNA extraction and array-based CGH}

Genomic DNA was isolated from tumor tissues using the Qiagen DNeasy Blood \& Tissue Kit as described by the manufacturer (Qiagen, Hilden, Germany).

Array CGH experiments were performed using standard Agilent protocols (Agilent Technologies, Santa Clara, CA). Commercial human genomic DNA (PROMEGA, Warrington, UK) was used as reference. For each CGH hybridization, $500 \mathrm{ng}$ of reference genomic DNA and the same amount of tumor DNA were digested with Alu I and RSA I restriction enzyme (PROMEGA, Warrington, UK).

Table 1 Clinical Characteristics of 16 Patients Studied by Array CGH

\begin{tabular}{lllll}
\hline Case No. & Sex & Age & Type & Location \\
\hline 1 & F & 52 & Adenoma & Rectum \\
2 & F & 49 & Adenoma & Rectum \\
3 & M & 75 & Adenoma & Rectum \\
4 & M & 47 & Adenoma & Rectum \\
5 & M & 57 & Adenoma & Rectum \\
6 & F & 61 & Adenoma & Rectum \\
7 & M & 69 & Adenoma & Rectum \\
8 & F & 75 & Adenoma & Rectum \\
9 & M & 69 & Carcinoma & Rectum \\
10 & M & 61 & Carcinoma & Rectum \\
11 & F & 70 & Carcinoma & Rectum \\
12 & F & 73 & Carcinoma & Rectum \\
13 & M & 42 & Carcinoma & Rectum \\
14 & M & 32 & Carcinoma & Rectum \\
15 & F & 31 & Carcinoma & Rectum \\
16 & M & 66 & Carcinoma & Rectum \\
\hline
\end{tabular}

The digested reference DNA fragments were labeled with cyanine-3 dUTP and the tumor DNA with cyanine-5 dUTP (Agilent Technologies, Santa Clara, CA). After clean-up, reference and tumor DNA probes were mixed and hybridized onto Agilent 44K human genome CGH microarray (Agilent) for $40 \mathrm{~h}$. Washing, scanning and data extraction procedures were performed following standard protocols.

Array CGH data set is available at Gene Expression Omnibus (GEO) http://www.ncbi.nlm.nih.gov/geo/[10], accession number GSE34472.

\section{Microarray data analysis}

Microarray data were analyzed using Agilent Genomic Workbench (Agilent Technologies, Santa Clara, CA) and MD-SeeGH (www.flintbox.ca). The Aberration Detection Method 2 algorithm with threshold at 6 (Agilent Genomic Workbench) was applied to identify common genomic aberrations. Mean Log2 ${ }^{\text {ratio }}$ of all probes in a chromosome region between 0.125 and 0.5 was classified as genomic gain, $>0.5$ as high-level DNA amplification, $<-0.125$ as hemizygous loss, and $<-0.5$ as homozygous deletion. Minimal regions of gains or losses in our study defined as the smallest overlapping aberrant chromosomal regions identified by Agilent Genomic Workbench. Frequency plot comparison method (MD-SeeGH) was used to compare frequency of DNA copy number changes between rectal adenoma and carcinoma.

\section{Total RNA extraction and real-time PCR}

Total RNA was isolated from tissues using the RNeasy Mini Kit as described by the manufacturer (Qiagen, Hilden, Germany).

The PCR reactions were performed in a total volume of $20 \mu \mathrm{l}$, including $10 \mu \mathrm{l}$ of $2 \mathrm{X} \mathrm{SYBR}{ }^{\circledR}$ Green PCR Master Mix (Applied Biosystems, Warrington, UK), $2 \mu \mathrm{l}$ of cDNA (5 ng/ $\mu \mathrm{l}), 1 \mu \mathrm{l}$ of primer mix (10 $\mu \mathrm{M}$ each). The PCR amplification and detection were carried out in a 7300 Real Time PCR System (Applied Biosystems) for 45 cycles, each with $15 \mathrm{~s}$ at $95{ }^{\circ} \mathrm{C}, 1 \mathrm{~min}$ at $60{ }^{\circ} \mathrm{C}$, and initial denaturation with $10 \mathrm{~min}$ at $95{ }^{\circ} \mathrm{C}$. The relative gene expression was calculated using the comparative CT Method [11]. The copy number of the target gene normalized to an endogenous reference (GAPDH), and relative to calibrator was given by the formula $2-\Delta \Delta \mathrm{Ct}$. $\triangle \mathrm{CT}$ was calculated by subtracting the average GAPDH CT from the average CT of the gene of interest. The ratio defines the level of relative expression of the target gene to that of GAPDH.

\section{Immunohistochemical staining}

Formalin-fixed, paraffin-embedded specimens of rectal adenoma and carcinoma were detected in immunohistochemistry assay. Tissues of each case were repeated for three times. The slides were deparaffinized, rehydrated, immersed in 
$3 \%$ hydrogen peroxide solution for $10 \mathrm{~min}$, heated in citrate buffer ( $\mathrm{pH} \mathrm{6)}$ for $25 \mathrm{~min}$ at $95^{\circ} \mathrm{C}$, and cooled for 60 min at room temperature. The slides were blocked by $10 \%$ normal goat serum for $30 \mathrm{~min}$ at $37^{\circ} \mathrm{C}$ and then incubated with rabbit polyclonal antibody against DIS3 (PTGLab), rabbit polyclonal antibody against GPNMB (PTGLab) overnight at $4^{\circ} \mathrm{C}$. After being washed with PBS, the slides were incubated with biotinylated secondary antibody (diluted 1:100) for $30 \mathrm{~min}$ at $37^{\circ} \mathrm{C}$, followed by streptavidinperoxidase (1:100 dilution) incubation for $30 \mathrm{~min}$ at $37^{\circ}$ C. Immunolabeling was visualized with a mixture of 3,3'diaminobenzidine solution. Counterstaining was carried out with hematoxylin.
Expression level was determined on the basis of staining intensity and percentage of immunoreactive cells. Negative expression $($ score $=0$ ) was no or faint staining, or moderate to strong staining in $<25 \%$ of cells. Weak expression (score $=1$ ) was a moderate or strong staining in $25 \%$ to $50 \%$ of cells. And strong expression (score =2) was $>50 \%$ of the cells with strong staining. Weak expression and strong expression defined as positive staining.

\section{Statistical analysis}

Statistical analyses were conducted using the Student's ttest and performed with the statistical software SPSS 15.0. The differences were judged as statistically

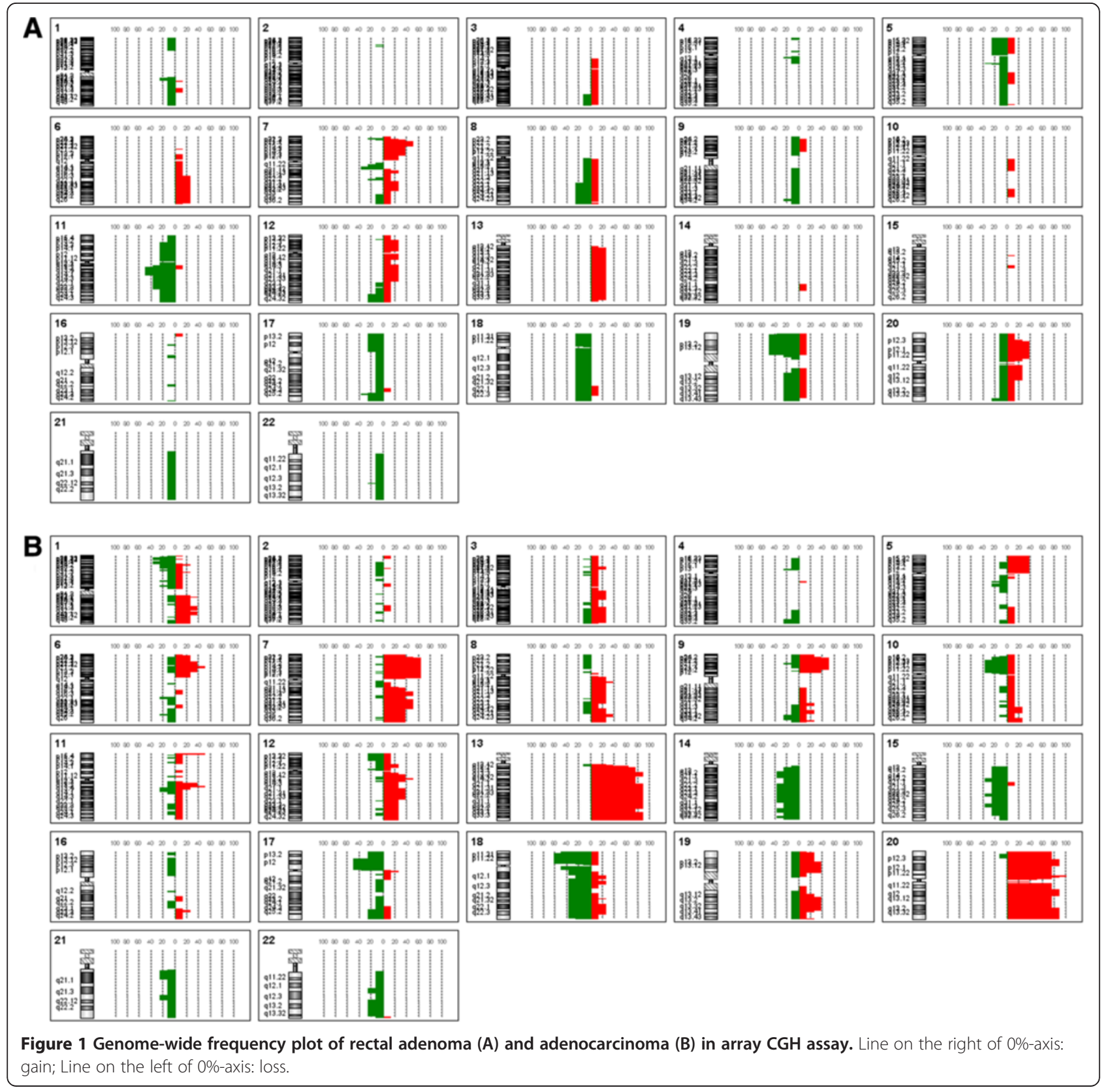


significant when the corresponding two-sided $\mathrm{P}$ value were $<.05$.

\section{Results}

Recurrent copy number alterations in rectal adenoma and carcinoma detected by array CGH

Seven out of eight adenomas and all of carcinomas had genomic aberrations. More alterations were observed in patients of rectal cancer than adenoma, and the numbers of changes were $39.13 \pm 20.48$ and $14.3 \pm 6.164$, respectively (Additional file 1: Figure S1). Array CGH results showed that the most frequent copy number alterations in rectal adenoma were gains of $7 \mathrm{p} 21.3-$ p15.3 and 20p12.3-p11.21 and losses of 5q13.2, 7q11.23, 11q13.1-q14.1, 17q25.1 and 19p13.3-p13.11 (Figure 1A, Tables 2 and 3). And the most common genetic aberrations in rectal carcinoma were gains of $7 \mathrm{p} 21.3-\mathrm{p} 15.3$, 7p15.3-p14.1, 7p14.1-p13, 7p13-p11.2, 13q13.1-q14.11, 13q21.1-q32.1, 13q32.1-q34, 20p11.21, 20q11.23-q12 and 20q13.2-q13.33 and losses of 17p13.1-p11.2, 18p11.32-p11.21 and 18q11.1-q11.2 (Figure 1B, Tables 2 and 3).

Table 2 Genomic Gains in Rectal Adenoma and Adenocarcinoma

\begin{tabular}{|c|c|c|c|c|c|c|c|c|}
\hline \multirow[t]{2}{*}{ Chromosome Region } & \multicolumn{4}{|c|}{ Rectal adenoma } & \multicolumn{4}{|c|}{ Rectal adenocarcinoma } \\
\hline & Start & End & $\begin{array}{l}\text { No. of } \\
\text { probes }\end{array}$ & $\begin{array}{l}\text { No. of } \\
\text { cases }\end{array}$ & Start & End & $\begin{array}{l}\begin{array}{l}\text { No. of } \\
\text { probes }\end{array} \\
\end{array}$ & $\begin{array}{l}\text { No. of } \\
\text { cases }\end{array}$ \\
\hline $1 q 21.3$ & & & & & 150819451 & 150852905 & 3 & 3 \\
\hline $1 q 25.3-q 31.3$ & & & & & 183720174 & 197184608 & 157 & 3 \\
\hline $1 q 32.1-q 41$ & & & & & 204180950 & 214439909 & 173 & 3 \\
\hline 5p13.3-p12 & & & & & 33503866 & 45681293 & 165 & 3 \\
\hline 6p21.33-p21.31 & & & & & 30737615 & 33655570 & 151 & 4 \\
\hline $6 q 16.3-q 27$ & 100547312 & 168205989 & 848 & 2 & & & & \\
\hline 7p21.3-p15.3 & 11041844 & 23202043 & 119 & 4 & 7671318 & 23172047 & 142 & 5 \\
\hline 7p15.3-p14.1 & & & & & 23821348 & 39813908 & 231 & 5 \\
\hline 7p14.1-p13 & & & & & 40099046 & 44497196 & 64 & 5 \\
\hline 7p13-p11.2 & & & & & 44890654 & 55242365 & 111 & 5 \\
\hline $7 q 21.11-q 21.12$ & 81196827 & 86205180 & 42 & 2 & & & & \\
\hline $7 q 21.12-q 21.3$ & & & & & 87207024 & 97321855 & 144 & 4 \\
\hline 7q22.3-q32.1 & 106191096 & 127234809 & 245 & 2 & 105253205 & 127519635 & 260 & 4 \\
\hline $8 q 12.1$ & & & & & 59565778 & 61340797 & 21 & 3 \\
\hline $8 q 24.21-q 24.22$ & & & & & 128816904 & 133653633 & 42 & 3 \\
\hline 9p24.1-p21.1 & & & & & 7058096 & 31463899 & 251 & 4 \\
\hline $11 \mathrm{p} 15.5$ & & & & & 192958 & 2278596 & 76 & 4 \\
\hline $11 q 13.2$ & & & & & 66917525 & 67689856 & 30 & 4 \\
\hline 12p13.31-p11.21 & 9053548 & 30700931 & 337 & 2 & & & & \\
\hline $12 q 12-q 13.11$ & 37052371 & 47174877 & 139 & 2 & & & & \\
\hline $12 q 13.13$ & & & & & 50568352 & 51486634 & 34 & 4 \\
\hline $12 q 14.1-q 22$ & 57350276 & 91428773 & 354 & 2 & & & & \\
\hline \multirow[t]{3}{*}{$13 q 13.1-q 14.1113 q 21.1-q 32.113 q 32.3-q 34$} & 21038984 & 109780488 & 909 & 2 & 32490193 & 39679219 & 79 & 7 \\
\hline & & & & & 52774228 & 94079000 & 275 & 7 \\
\hline & & & & & 100091512 & 114022929 & 148 & 7 \\
\hline 19p13.2-p13.11 & & & & & 9800520 & 19631574 & 473 & 3 \\
\hline $19 q 13.13-q 13.33$ & & & & & 43396893 & 55615310 & 550 & 3 \\
\hline 20p11.21 & 7296794 & 23132344 & 189 & 3 & 22510206 & 23380542 & 15 & 8 \\
\hline $20 q 11.23-q 12$ & 29592072 & 42681834 & 275 & 2 & 35467169 & 41087006 & 78 & 7 \\
\hline $20 q 13.2-q 13.33$ & & & & & 52017030 & 62323759 & 215 & 7 \\
\hline
\end{tabular}

Note: The number of rectal adenoma and adenocarcinoma in Array CGH study are both 8 cases. 
Table 3 Genomic Losses in Rectal Adenoma and Adenocarcinoma

\begin{tabular}{|c|c|c|c|c|c|c|c|c|}
\hline \multirow[t]{2}{*}{ Chromosome Region } & \multicolumn{4}{|c|}{ Rectal adenoma } & \multicolumn{4}{|c|}{ Rectal adenocarcinoma } \\
\hline & Start & End & $\begin{array}{l}\text { No. of } \\
\text { probes }\end{array}$ & $\begin{array}{l}\text { No. of } \\
\text { cases }\end{array}$ & Start & End & $\begin{array}{l}\text { No. of } \\
\text { probes }\end{array}$ & $\begin{array}{l}\text { No. of } \\
\text { cases }\end{array}$ \\
\hline 1p36.23-p36.22 & & & & & 7804415 & 11633739 & 82 & 3 \\
\hline 1 p36.22-p36.13 & & & & & 12600054 & 16167534 & 41 & 3 \\
\hline 1p36.12-p35.3 & & & & & 21802142 & 29525663 & 226 & 3 \\
\hline $1 q 21.2-q 21.3$ & 148163183 & 149505863 & 60 & 2 & & & & \\
\hline $1 q 21.3-q 23.1$ & 151880217 & 155031244 & 154 & 2 & & & & \\
\hline $4 q 12$ & 55913547 & 57653302 & 38 & 2 & & & & \\
\hline 5p15.33-p12 & 260981 & 45865412 & 433 & 2 & & & & \\
\hline $5 q 13.2$ & 68434643 & 68900029 & 18 & 3 & & & & \\
\hline 7p22.2-p22.1 & 4298590 & 6547570 & 42 & 2 & & & & \\
\hline $7 q 11.23$ & 72003839 & 75977276 & 77 & 3 & & & & \\
\hline $7 q 22.1$ & 99538250 & 101895994 & 79 & 2 & & & & \\
\hline $8 q 22.2-q 24.3$ & 100781187 & 143914353 & 448 & 2 & & & & \\
\hline $8 q 24.3$ & 143914353 & 146250824 & 75 & 2 & & & & \\
\hline $9 q 34.11$ & 130111425 & 132321365 & 64 & 2 & & & & \\
\hline 10p14-p11.21 & & & & & 11825924 & 35645512 & 315 & 3 \\
\hline 11p15.2-p11.12 & 14750051 & 50638829 & 468 & 2 & & & & \\
\hline $11 q 13.1-q 14.1$ & 63802950 & 80046693 & 442 & 4 & & & & \\
\hline $12 q 24.23-q 24.33$ & 116956235 & 132193660 & 257 & 2 & & & & \\
\hline $14 q 12-q 21.1$ & & & & & 30209271 & 38927323 & 130 & 3 \\
\hline $14 q 22.1-q 24.3$ & & & & & 48874529 & 77750644 & 544 & 3 \\
\hline $14 q 31.3-q 32.1$ & & & & & 87763614 & 93260389 & 110 & 3 \\
\hline 14q32.2-q32.32 & & & & & 99254905 & 102592287 & 70 & 3 \\
\hline $15 q 15.1-q 21.1$ & & & & & 38653893 & 42843706 & 119 & 3 \\
\hline $15 q 22.31$ & & & & & 61519869 & 64628895 & 74 & 3 \\
\hline $15 q 25.1-q 25.2$ & & & & & 76206143 & 79967204 & 77 & 3 \\
\hline 17p13.1-p11.2 & 84287 & 21386319 & 606 & 2 & 8327645 & 20974722 & 266 & 4 \\
\hline $17 q 25.1$ & 70528777 & 71603516 & 61 & 3 & & & & \\
\hline 18p11.32-p11.21 & 170229 & 13875315 & 173 & 2 & 2580000 & 13752309 & 137 & 5 \\
\hline $18 q 11.1-q 11.2$ & 16904187 & 76018409 & 684 & 2 & 16976046 & 20313378 & 51 & 4 \\
\hline 19p13.3-p13.11 & 1432408 & 19699544 & 795 & 4 & & & & \\
\hline $19 q 13.11-q 13.43$ & 37554715 & 63672832 & 1114 & 2 & & & & \\
\hline $20 q 13.33$ & 60039825 & 62320720 & 85 & 2 & & & & \\
\hline $22 q 13.1$ & 37689058 & 37715431 & 3 & 2 & & & & \\
\hline
\end{tabular}

Note: The number of rectal adenoma and adenocarcinoma in Array CGH study are both 8 cases.

Common and distinct genomic events in rectal adenoma and carcinoma

By comparing the genomic aberrations of rectal adenoma and carcinoma, we found that gains of $7 \mathrm{p} 21.3-$ p15.3, 7q22.3-q32.1, 13q13.1-q14.11, 13q21.1-q32.1, 13q32.3-q34, 20p11.21 and 20q11.23-q12 and losses of 17p13.1-p11.2, 18p11.32-p11.21, and 18q11.1-q11.2 were shared by rectal adenoma and carcinoma. However, gains of 1q, 6p21.33-p21.31 and losses of 10p14-p11.21, 14q12-q21.1, 14q22.1-q24.3, 14q31.3-q32.1, 14q32.2q32.32, 15q15.1-q21.1, 15q22.31 and 15q25.1-q25.2 were detected in carcinoma but not in adenoma (Figure 2, Tables 2 and 3).

\section{Candidate target genes of interesting gains and losses}

Further, we selected 14 genes of 1q, 6p, 7p, 13q, 18q and $20 \mathrm{q}$ to analyze the mRNA expression by realtime PCR (Table 4). Array CGH found that copy 


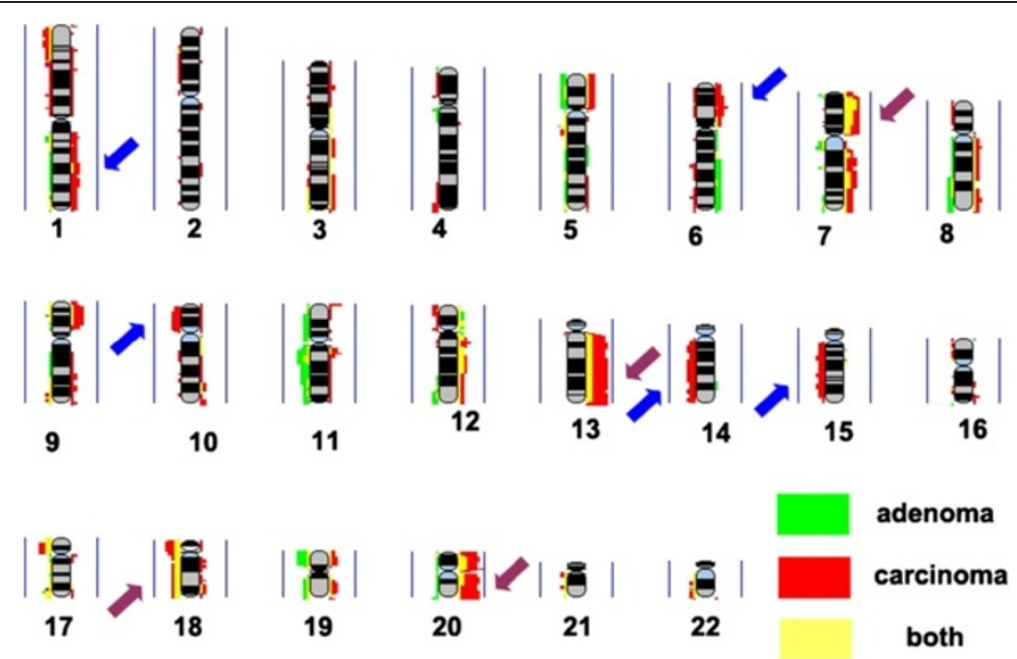

Figure 2 Frequency plot comparison of rectal adenoma and carcinoma. Red: carcinoma; green: adenoma; yellow: shared by both. The presentation is per array probe; gains and losses are represented by the colors on the right and left, respectively. Vertical blue line represents $100 \%$ of the samples. Brown and blue arrows highlight the changed chromosomal areas that were common or distinct between rectal adenoma and carcinoma, respectively.

number increase of GPNMB (7p15.2), OXGR1 (13q32.1), C13orf27 (13q32.2-q34), PMEPA1 (20q13.31), PHACTR3 (20q13.32) and decrease of SMAD4 (18q21.2), BCL2 (18q21.33) occurred in both rectal adenoma and carcinoma. Our real-time PCR results showed that $\mathrm{C} 13$ orf27 and PMEPA1 were overexpressed in rectal cancer tissues comparing with paracancerous normal tissues. BCL2 and SMAD4 were underexpressed in tumor tissue (Figure 3A). And the expression level of C13orf27 and GPNMB was significantly higher in cancer tissues than rectal adenoma tissues (Figure 3B).
Copy number increase of EFNA1 (1q22), PTGS2 (1q31.1), KDM5B (1q32.1), ESRRG (1q41), KIFC1 (6p21.32), PBX2 (6p21.32) and SOX4 (6p22.3) were only detected in rectal cancer in array $\mathrm{CGH}$. Among them, EFNA1 had increased expression in carcinoma compared with adenoma, and KIFC1 had an upward trend but not significant in statistical analysis (Figure 4A). Of these genes KIFC1 and SOX4 were also significantly overexpressed in rectal tumor tissues than paracancerous tissues (Figure 4B).

We also analyzed the protein expression of GPNMB (7p15.2) and DIS3 (13q22.1) by immunohistochemistry.

Table 4 Primers of genes in Real-time PCR assay

\begin{tabular}{|c|c|c|c|}
\hline Gene & Forward primer & Backward primer & Size (bp) \\
\hline$\overline{\text { GAPDH }}$ & GGTCGTATTGGGCGCCTGGTC & TGACGGTGCCATGGAATTTGCCA & 148 \\
\hline KIFC1 & TCTCTGGGTGGTAGTGCTAAGA & TAAGTCACTTCCTGTTGGCCTG & 148 \\
\hline SOX4 & GACCGGGACCTGGATTTTAACT & TGAAAACCAGGTTGGAGATGCT & 133 \\
\hline PBX2 & AAGTTCCAAGAGGAGGCAAACA & TCCTGAGAGATTGAAAGAGCCG & 132 \\
\hline ESRRG & GCTATCCTGCAGCTGGTAAAGA & GCTATCCTGCAGCTGGTAAAGA & 133 \\
\hline KDM5B & CCCTCAGACACATCCTATTCCG & CAGTCCACCTCATCTCCTTCTG & 101 \\
\hline PTGS2 & TGTATCCTGCCCTTCTGGTAGA & AAGGAGAATGGTGCTCCAACTT & 85 \\
\hline EFNA1 & GTGGCAAAATCACTCACAGTCC & CTATGTAGAACCCGCACCTCTG & 91 \\
\hline $\mathrm{BCL} 2$ & AGGATTGTGGCCTTCTTTGAGT & CGGTTCAGGTACTCAGTCATCC & 113 \\
\hline SMAD4 & TGTTGATGACCTTCGTCGCTTA & ATGCTCTGTCTTGGGTAATCCG & 81 \\
\hline PHACTR3 & TATGACAGGAGGGCAGACAAAC & GCTTGCTTGATGCATGTACCTC & 118 \\
\hline C13orf27 & TCAGGCTCAGCAGATGAAATGT & TCCAGTGGATTTATGGGGAGC & 85 \\
\hline PMEPA & CTGAGCCACTACAAGCTGTCTG & СTTCTGAGGACAGGGCATCTTC & 85 \\
\hline OXGR1 & ATCTTGAGGGTCATTCGGATCG & TGTCGCTGACCACCACATATAG & 148 \\
\hline GPNMB & GTCACTGTGATCTCCCTCTTGG & TाTGCACGGTTGAGAAAGACAC & 116 \\
\hline
\end{tabular}



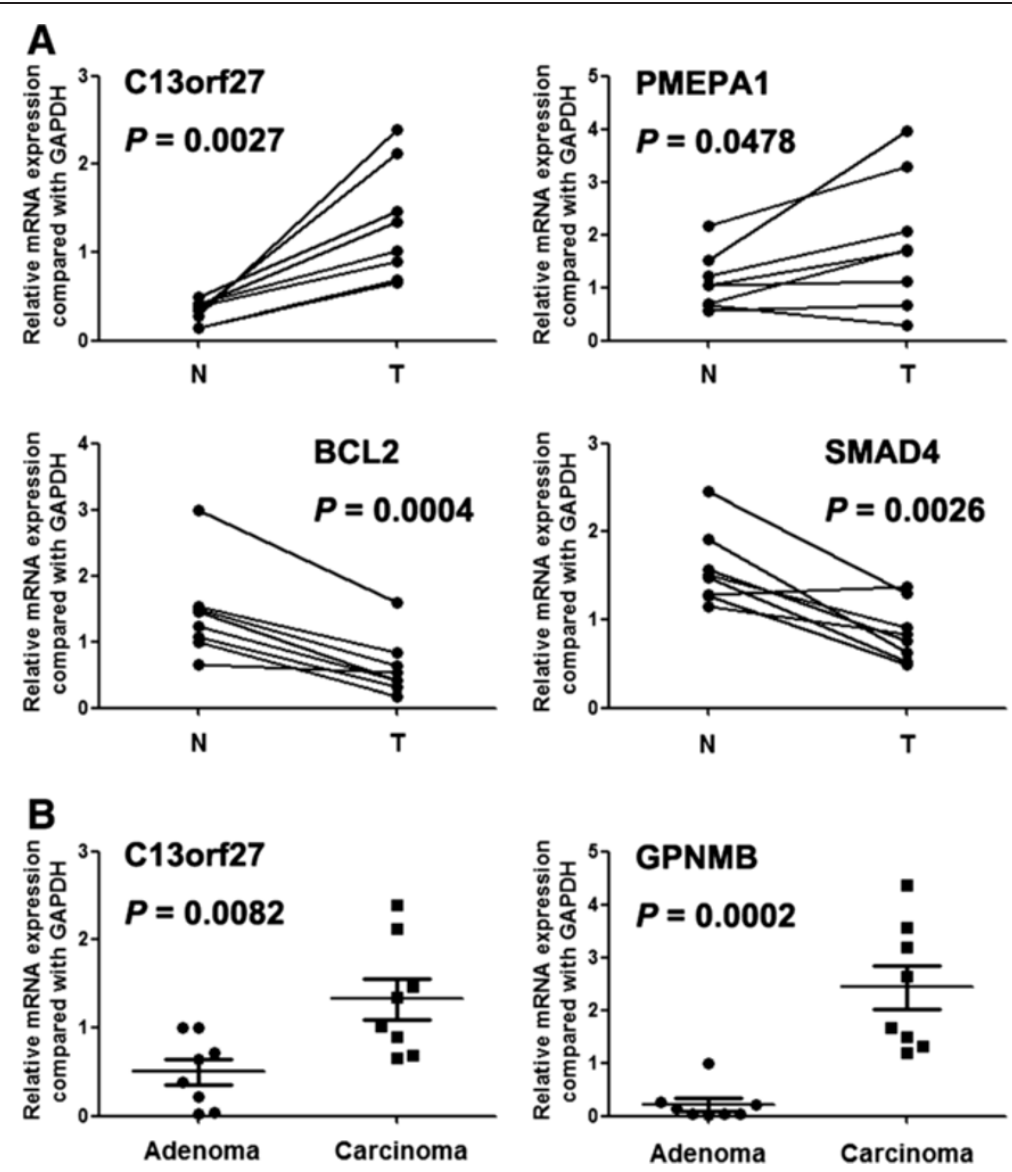

Figure 3 Expression of genes which were located on the common aberrant chromosomal regions in rectal adenoma and carcinoma. $\mathrm{N}$ : paracancerous normal tissues; T: rectal cancer tissues.

Of all six detected rectal adenoma tissues, GPNMB and DIS3 had no expression. In twenty rectal cancer tissues, GPNMB and DIS3 were positively stained in six and five cases, respectively (Figure 5).

\section{Discussion}

In the past decades, a number of genomic changes were found in colorectal adenoma and carcinoma, but the target genes are limited and molecular mechanism of adenoma to carcinoma progression is still unknown.

Previous studies found that $8 \mathrm{q}, 13 \mathrm{q}$ and $20 \mathrm{q}$ gains and $8 \mathrm{p}, 15 \mathrm{q}$ and $18 \mathrm{q}$ losses are linked with colorectal adenoma to carcinoma progression [4-9]. Our study narrowed down the gain regions to $13 \mathrm{q} 13.1-\mathrm{q} 14.11$, 13q21.1-q32.1, 13q32.2-q34 and 20q11.23-q12 and the loss regions to $18 \mathrm{q} 11.2$. Furthermore, gains of $7 \mathrm{p} 21.3$ p15.3 and $7 q 22.3-q 32.1$ and losses of 17p13.1-p11.2, 18p11.32-p11.21 were also found in both rectal adenoma and carcinoma.

Our study also showed that some genomic aberrations were present in rectal tumor but not in adenoma. They are gains of $1 \mathrm{q}$ and $6 \mathrm{p} 21.33$ and losses of 10p14-p11.21, 14q12-q21.1, 14q22.1-q24.3, 14q31.3-q32.1, 14q32.2$\mathrm{q} 32.32, \quad 15 \mathrm{q} 15.1-\mathrm{q} 21.1, \quad 15 \mathrm{q} 22.31$ and $15 \mathrm{q} 25.1-\mathrm{q} 25.2$. These aberrations occurred at the later stages of rectal carcinogenesis, and may contribute the progression from adenoma to carcinoma.

Identifying the candidate targets underlying the genomic aberrations was important for understanding the mechanism of carcinogenesis. Carvalho et al. found that the overexpressions of C20orf24, AURKA, RNPC1, TH1L, ADRM1, C20orf20 and TCRL5 in carcinomas compared with adenomas were correlated with 20q gain [4]. Habermann et al. showed that copy number changes of $7 q, 8 p, 8 q, 13 q, 18 p, 18 q, 20 p$ and $20 q$ deregulated the average expression levels of the genes on these chromosome arms [12]. However, most of samples detected in these reports were colon cancer which had some different genomic aberrations compared with rectal cancer [13], expression-dysregulated genes in the carcinogenesis of rectum were still limited. By literature analyses, we selected 14 genes to compare their expression between in tumor and paracancerous tissues or 

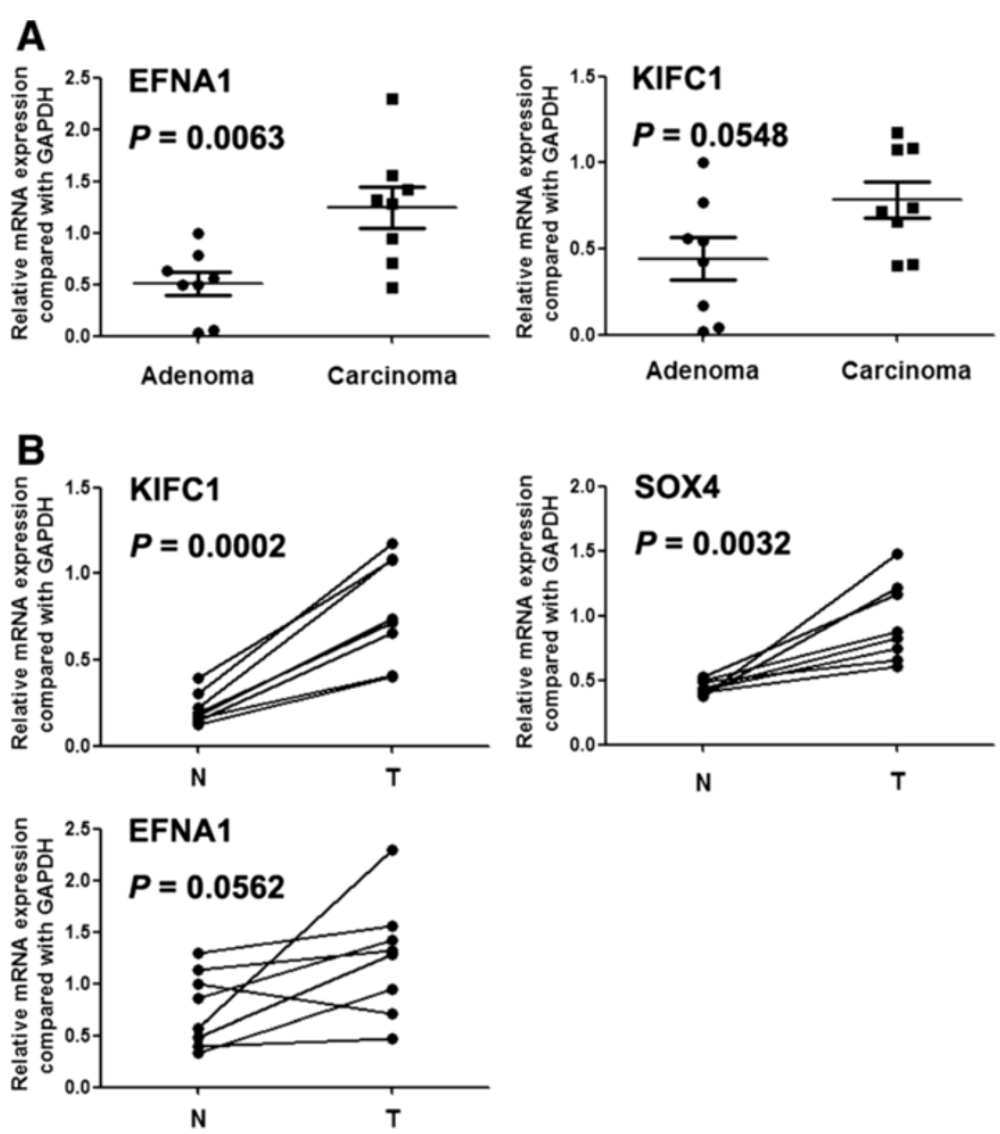

Figure 4 Expression of genes which were located on the distinct aberrant chromosomal regions in rectal adenoma and carcinoma.

$\mathrm{N}$ : paracancerous normal tissues; T: rectal cancer tissues.

between in rectal adenoma and carcinoma tissues. Of them, copy number and mRNA expression of EFNA1 increased from rectal adenoma to carcinoma, and C13orf27 and PMEPA1 with gains in both adenoma and carcinoma were overexpressed in rectal cancer tissues. These results revealed that copy number increase maybe the reason of expression up-regulation. Interestingly, both mRNA and protein expression of GPNMB was higher in cancer tissues than rectal adenoma tissues.

GPNMB is a type I transmembrane protein and overexpressed in several malignant human tissues relative to the corresponding normal tissues. Ectopic overexpression of GPNMB/osteoactivin can promote the metastasis and invasion of glioma, breast and hepatocellular carcinoma [14-17]. EFNA1 was overexpressed in hepatocellular carcinoma and can inhibit growth of malignant mesothelioma by phosphorylating EPHA2 [18,19]. C13orf27 was overexpressed in rectal tumor in our study, but the function of C13orf27 was unknown. PMEPA1 was also identified in our study, which is mapped to $20 \mathrm{q} 13.3$ is a TGF-beta inducible gene and encodes a NEDD4 E3 ubiguitin ligase binding protein.
PMEPA1 is over-expressed in prostate, breast, renal cell, stomach and rectal carcinomas [20-22]. But little is known about the function of PMEPA1, Further study should be conducted to investigate the roles of the above genes in human colorectal cancer.

Loss of $18 \mathrm{q}$ is a common event in colorectal cancer, and $18 \mathrm{q}$ deletion and loss of SMAD4 expression are associated with liver metastasis. In colorectal cancer, patients with reduced SMAD4 expression frequently presented an unfavorable survival because of liver metastasis [23-26]. High expression level of SMAD4 reflected significantly longer overall and disease-free survival time than low expression level [27]. Bixiang et al. found that transgenic expression of SMAD4 can significantly reduce the oncogenic potential of MC38 and SW620 cells [28]. Our study confirmed the decreased expression of SMAD4 in rectal cancer.

In summary, we identified EFNA1 (1q), C13orf27 (13q), PMEPA1 (20q), GPNMB (7q) as candidate driving genes of genomic aberrations in rectal cancer. Further study was needed to reveal the mechanisms by which these genes may be involved in the carcinogenesis of the rectum. 

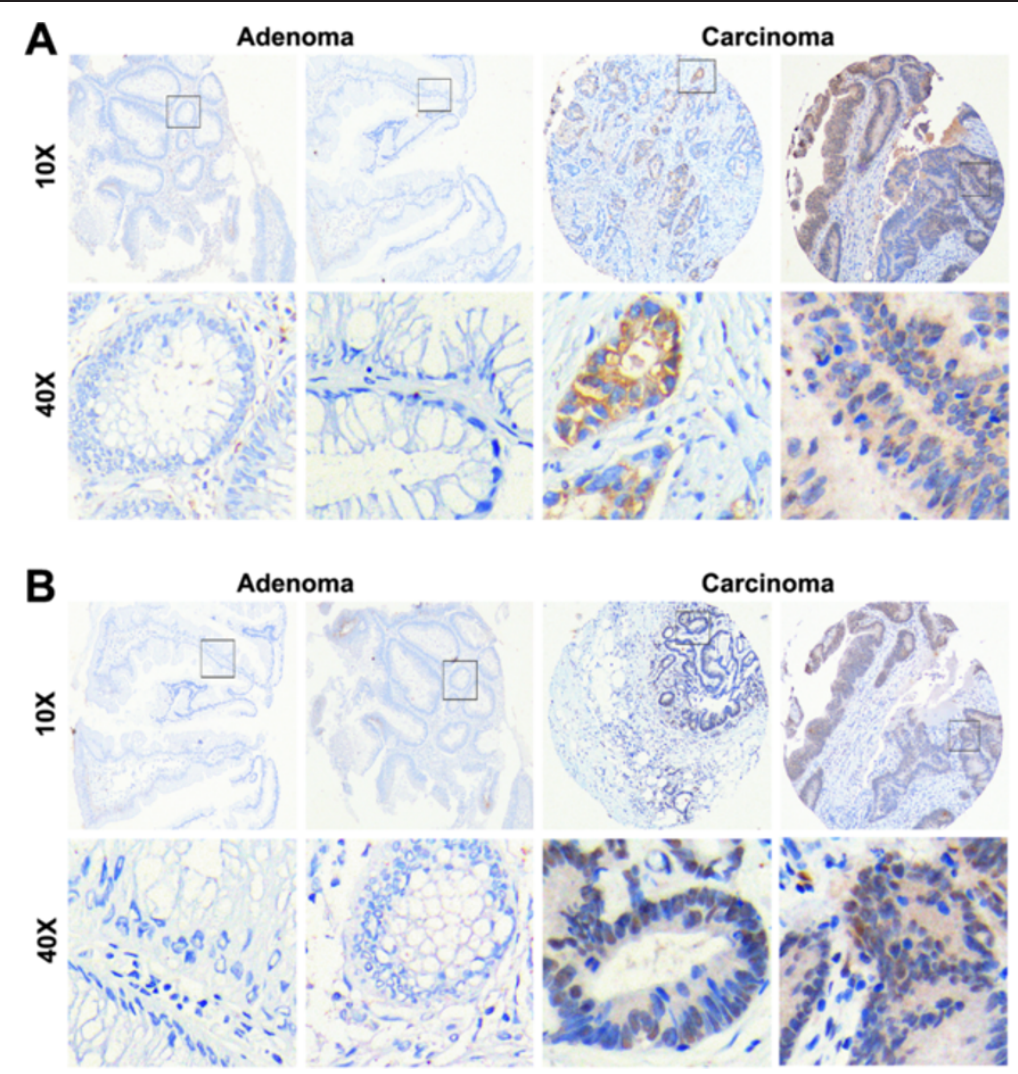

Figure 5 Expression of GPNMB and DIS3 by immunohistochemistry assay.

\section{Conclusions}

Our data provide detailed information on genomic aberrations present in rectal adenoma or carcinoma, especially both in two groups or only in rectal cancer. Real-time PCR and immunohistochemistry assay selected EFNA1, C13orf27, PMEPA1 and GPNMB as candidate amplification targets. Our results may help to identify the driving genes involved in the adenoma-carcinoma progression.

\section{Additional file}

Additional file 1: Figure S1. Comparison of rectal adenoma and

carcinoma in number of genomic aberrations.

\section{Competing interests}

The authors declared that they have no competing interest.

\section{Authors' contributions}

ZYM participated in the collection of specimens. HJJ prepared the genomic DNA and total RNA. SZZ carried out the array CGH study. WBS performed microarray data analysis, LJW, CX and ZY carried out the real-time PCR assay. SL and ZTT performed immunohistochemistry assay. SZZ, WMR, WGQ and ZY participated in the design of the study and performed the statistical analysis. All authors read and approved the final manuscript.

\section{Acknowledgements}

The authors would like to thank Kai-Tai Zhang, Department of Etiology and Carcinogenesis of Peking Union Medical College as the help of array CGH experiment.

\section{Funding}

Supported by: This work was supported by Special Public Health Fund of China (200902002-5) and Chinese Hi-Tech R\&D Program Grant (2011YQ17006710).

\section{Author details}

${ }^{1}$ State Key Laboratory of Molecular Oncology, Cancer Institute /Hospital, Peking Union Medical College and Chinese Academy of Medical Sciences, Beijing, China. ${ }^{2}$ Department of Endoscopy, Cancer Institute (Hospital), Peking Union Medical College and Chinese Academy of Medical Sciences, Beijing, China. ${ }^{3}$ Department of Abdominal Surgery, Cancer Institute/Hospital, Peking Union Medical College and Chinese Academy of Medical Sciences, Beijing, China.

Received: 7 December 2011 Accepted: 18 October 2012 Published: 16 November 2012

\section{References}

1. Li M, Gu J: Changing patterns of colorectal cancer in China over a period of 20 years. World J Gastroenterol 2005, 11:4685-4688.

2. Fearon $E R$, Vogelstein B: A genetic model for colorectal tumorigenesis. Cell 1990, 61:759-767.

3. Muto T, Bussey HJ, Morson BC: The evolution of cancer of the colon and rectum. Cancer 1975, 36:2251-2270.

4. Carvalho C, Postma S, Mongera E, Hopmans S, Diskin MA, van de Wiel, Van Criekinge W, Thas O, Matthai A, Cuesta MA, Terhaar Sive Droste JS, Craanen M, Schrock E, Ylstra B, Meijer GA: Multiple putative oncogenes at the 
chromosome 20q amplicon contribute to colorectal adenoma to carcinoma progression. Gut 2009, 58:79-89.

5. Diep CB, Kleivi K, Ribeiro FR, Teixeira MR, Lindgjaerde OC, Lothe RA: The order of genetic events associated with colorectal cancer progression inferred from meta-analysis of copy number changes. Genes Chromosomes Cancer 2006, 45:31-41.

6. Hoglund M, Gisselsson D, Hansen GB, Sall T, Mitelman F, Nilbert M: Dissecting karyotypic patterns in colorectal tumors: two distinct but overlapping pathways in the adenoma-carcinoma transition. Cancer Res 2002, 62:5939-5946

7. Douglas EJ, Fiegler H, Rowan A, Halford S, Bicknell DC, Bodmer W, Tomlinson IP, Carter NP: Array comparative genomic hybridization analysis of colorectal cancer cell lines and primary carcinomas. Cancer Res 2004, 64:4817-4825.

8. Nakao K, Mehta KR, Fridlyand J, Moore DH, Jain AN, Lafuente A, Wiencke JW, Terdiman JP, Waldman FM: High-resolution analysis of DNA copy number alterations in colorectal cancer by array-based comparative genomic hybridization. Carcinogenesis 2004, 25:1345-1357.

9. Ried T, Knutzen R, Steinbeck R, Blegen H, Schrock E, Heselmeyer K, du Manoir S, Auer G: Comparative genomic hybridization reveals a specific pattern of chromosomal gains and losses during the genesis of colorectal tumors. Genes Chromosomes Cancer 1996, 15:234-245.

10. Edgar R, Domrachev M, Lash AE: Gene Expression Omnibus: NCBI gene expression and hybridization array data repository. Nucleic Acids Res 2002, 30:207-210.

11. Wang G, Brennan C, Rook M, Wolfe JL, Leo C, Chin L, Pan H, Liu WH, Price B, Makrigiorgos GM: Balanced-PCR amplification allows unbiased identification of genomic copy changes in minute cell and tissue samples. Nucleic Acids Res 2004, 32:e76.

12. Habermann JK, Paulsen U, Roblick UJ, Upender MB, McShane LM, Korn EL, Wangsa D, Kruger S, Duchrow M, Bruch HP, Auer G, Ried T: Stage-specific alterations of the genome, transcriptome, and proteome during colorectal carcinogenesis. Genes Chromosomes Cancer 2007, 46:10-26.

13. He QJ, Zeng WF, Sham JS, Xie D, Yang XW, Lin HL, Zhan WH, Lin F, Zeng SD, Nie D, Ma LF, Li CJ, Lu S, Guan XY: Recurrent genetic alterations in 26 colorectal carcinomas and 21 adenomas from Chinese patients. Cancer Genet Cytogenet 2003, 144:112-118.

14. Tse KF, Jeffers M, Pollack VA, McCabe DA, Shadish ML, Khramtsov NV, Hackett CS, Shenoy SG, Kuang B, Boldog FL, MacDougall JR, Rastelli L, Herrmann J, Gallo M, Gazit-Bornstein G, Senter PD, Meyer DL, Lichenstein HS, LaRochelle WJ: CR011, a fully human monoclonal antibody-auristatin E conjugate, for the treatment of melanoma. Clin Cancer Res 2006, 12:1373-1382

15. Onaga M, Ido A, Hasuike S, Uto H, Moriuchi A, Nagata K, Hori T, Hayash K, Tsubouchi H: Osteoactivin expressed during cirrhosis development in rats fed a choline-deficient, L-amino acid-defined diet, accelerates motility of hepatoma cells. J Hepatol 2003, 39:779-785.

16. Rich JN, Shi Q, Hjelmeland M, Cummings TJ, Kuan CT, Bigner DD, Counter CM, Wang XF: Bone-related genes expressed in advanced malignancies induce invasion and metastasis in a genetically defined human cancer model. J Biol Chem 2003, 278:15951-15957.

17. Rose AA, Pepin F, Russo C, Abou Khalil JE, Hallett M, Siegel PM: Osteoactivin promotes breast cancer metastasis to bone. Mol Cancer Res 2007, 5:1001-1014

18. Nasreen N, Mohammed KA, Lai Y, Antony VB: Receptor EphA2 activation with ephrinA1 suppresses growth of malignant mesothelioma (MM). Cancer Lett 2007, 258:215-222.

19. Cui XD, Lee MJ, Yu GR, Kim IH, Yu HC, Song EY, Kim DG: EFNA1 ligand and its receptor EphA2: potential biomarkers for hepatocellular carcinoma. Int J Cancer 2010, 126:940-949.

20. Giannini G, Ambrosini MI, Di Marcotullio L, Cerignoli F, Zani M, MacKay AR, Screpanti I, Frati L, Gulino A: EGF- and cell-cycle-regulated STAG1/ PMEPA1/ERG1.2 belongs to a conserved gene family and is overexpressed and amplified in breast and ovarian cancer. Mol Carcinog 2003, 38:188-200.

21. Rae FK, Hooper JD, Nicol DL, Clements JA: Characterization of a novel gene, STAG1/PMEPA1, upregulated in renal cell carcinoma and other solid tumors. Mol Carcinog 2001, 32:44-53.

22. Xu LL, Shanmugam N, Segawa T, Sesterhenn IA, McLeod DG, Moul JW Srivastava S: A novel androgen-regulated gene, PMEPA1, located on chromosome $20 \mathrm{q} 13$ exhibits high level expression in prostate. Genomics 2000, 66:257-263.

23. Miyaki M, lijima T, Konishi M, Sakai K, Ishii A, Yasuno M, Hishima T, Koike M, Shitara N, Iwama T, Utsunomiya J, Kuroki T, Mori T: Higher frequency of Smad4 gene mutation in human colorectal cancer with distant metastasis. Oncogene 1999, 18:3098-3103.

24. Losi L, Bouzourene H, Benhattar J: Loss of Smad4 expression predicts liver metastasis in human colorectal cancer. Oncol Rep 2007, 17:1095-1099.

25. Kawakami M, Yamaguchi T, Takahashi K, Matsumoto H, Yasutome M, Horiguchi S, Hayashi Y, Funata N, Mori T: Assessment of SMAD4, p53, and Ki-67 alterations as a predictor of liver metastasis in human colorectal cancer. Surg Today 2010, 40:245-250.

26. Tanaka T, Watanabe T, Kitayama J, Kanazawa T, Kazama Y, Tanaka J, Kazama $\mathrm{S}$, Nagawa H: Chromosome 18q deletion as a novel molecular predictor for colorectal cancer with simultaneous hepatic metastasis. Diagn Mol Pathol 2009, 18:219-225.

27. Alazzouzi H, Alhopuro P, Salovaara R, Sammalkorpi H, Jarvinen H, Mecklin JP, Hemminki A, Schwartz S Jr, Aaltonen LA, Arango D: SMAD4 as a prognostic marker in colorectal cancer. Clin Cancer Res 2005, 11:2606-2611.

28. Zhang B, Halder SK, Kashikar ND, Cho YJ, Datta A, Gorden DL, Datta PK: Antimetastatic role of Smad4 signaling in colorectal cancer. Gastroenterology 2010, 138:969-980. e961-963.

doi:10.1186/1755-8794-5-52

Cite this article as: Shi et al: Genomic profiling of rectal adenoma and carcinoma by array-based comparative genomic hybridization. BMC Medical Genomics 2012 5:52.

\section{Submit your next manuscript to BioMed Central and take full advantage of:}

- Convenient online submission

- Thorough peer review

- No space constraints or color figure charges

- Immediate publication on acceptance

- Inclusion in PubMed, CAS, Scopus and Google Scholar

- Research which is freely available for redistribution 